\title{
Does stress and university adjustment relate to health in peru? ${ }^{\text {is }}$
}

\author{
¿Se relacionan el estrés y el ajuste universitario con la salud en Perú? \\ ${\text { Cecilia } \text { Chau }^{*, 1} \text {, Juan Carlos Saravia }}^{1}$ \\ Universidad Católica de Perú, Departamento de Psicología, Lima, Perú
}

Received 10 November 2015; accepted 12 October 2016

\begin{abstract}
The aim of this study was to assess the relationship between university adaptation, perceived stress and mental and physical health. We also evaluated if perceived stress mediated the relationship between university adaptation and health. A cross-sectional study was carried out among general studies undergraduate students of one private university in Lima, Peru. The sample was composed of 200 students with an average of 18.13 years old $(S D=1.41)$. Multiple regression and mediation analyses were assessed to understand the relationship between university adaptation and health. Multiple linear regression estimations had the following results for mental and physical health. Interpersonal relationships in university better related to mental health. This model was composed by interpersonal relationships (Interpersonal), dedication to study and future career plans, which accounted for $23 \%$ of the whole model. Physical health model was composed of perceived stress and study which accounted for $22 \%$ of the whole model of physical health. Mediation analysis showed that perceived stress fully mediated the relationship between study and physical health. Our findings could help further understand how college students are adjusting in order to have a better health. These findings have important implications on assessing interventions for students that are struggling to adapt to college demands.

(C) 2017 Universidad Nacional Autónoma de México, Asociación Mexicana de Comportamiento y Salud. This is an open access article under the CC BY-NC-ND license (http://creativecommons.org/licenses/by-nc-nd/4.0/).
\end{abstract}

Keywords: Peru; Health perception; University adaptation; Adolescent

\section{Resumen}

El objetivo de este estudio fue evaluar la relación entre adaptación universitaria, estrés percibido, salud mental y física. Además, se evaluó si el estrés percibido mediaba la relación entre adaptación y salud. Se realizó una investigación transeccional con estudiantes de estudios generales de una universidad de Lima, Perú. La muestra estuvo compuesta por 200 estudianes con un promedio de edad de 18.13 años $(D E=1.41)$. Un análisis de regresión múltiple y otro de mediación fueron utilizados para evaluar la relación entre adaptación y salud. La regresión múltiple arrojó que las relaciones interpersonales fueron las que mejor predecían la salud mental. Este modelo fue compuesto por las relaciones interpersonales, la dedicación hacia el estudio y las expectativas futuras de carrera, el cual explicó el $23 \%$ de la varianza. El modelo de salud física estuvo compuesto por las relaciones interpersonales y el estrés percibido, el cual explicó el $22 \%$ de la varianza. El estrés percibido mediaba completamente la relación entre dedicación hacia el estudio y salud física. Nuestros hallazgos podrían ayudar a enteder cómo los estudiantes se están adaptando para mantener una adecuada salud. Estos resultados tienen implicaciones importantes en la evaluación de las intervenciones para los estudiantes que están luchando para adaptarse a las demandas de la universidad.

(C) 2017 Universidad Nacional Autónoma de México, Asociación Mexicana de Comportamiento y Salud. Este es un artículo Open Access bajo la licencia CC BY-NC-ND (http://creativecommons.org/licenses/by-nc-nd/4.0/).

Palabras clave: Perú; Percepción de la salud; Adaptación a la universidad; Adolescentes

\footnotetext{
* Corresponding author.

E-mail address: cchau@pucp.edu.pe (C. Chau).

1 Each author contributed in the same proportion to each section of the paper.

is Peer review under the responsibility of Asociación Mexicana de Comportamiento y Salud.
} 


\section{Introduction}

Late adolescents and emerging adults have an important role in development of a nation because in the future they will become the main workforce of it. They will lead political, economical and social movements. In particular, in Peru a population between 15-29 years of age represents $27.2 \%$ of the whole population of the state. Moreover it is possible that in the year 2021 this group will increase to 8,512764 people (INEI, 2013).

Therefore, the health states of late adolescents and emerging adults is very important for this country. The health ministry has found out that in people between 18 and 29 years old, the most common diseases are the following: respiratory infections $(26.2 \%)$, oral diseases $(19.9 \%)$ and affections related to pregnancy (12.3\%) (MINSA, 2011).

A national study with adolescents showed that these late adolescents and emerging adults have also suffered from changes in their sleep patterns $(56.40 \%)$, feel tired or bored the majority of the day $(51.1 \%)$, suffer constant headache, neck and back pain $(47.5 \%)$ and also an important group of people (44.0\%) suffer from depressive and anxiety symptoms such as feelings of sadness and listlessness (SENAJU, 2012). Overall, the principal need this population has is the access to higher education (Ministerior de salud del Perú (MINSA), 2011). According to a Peruvian national study with adolescents, $15.6 \%$ of young people between 15-29 years have completed the first year of higher education. Moreover, the majority of people that where able to pass this level are between 25 and 29 years and old (23.0\%) and 20 to 24 years old (19.7\%) (SENAJU, 2012).

Going to university is a big challenge for late adolescents and emerging adults. In this path they have a lot of different challenges from and developmental perspective and an academic perspective. In the developmental level, this population has to face difficult tasks as a result of maturation. Physical and emotional changes transform the way they have to relate with peers and family. Moreover, this period is marked by an increase in psychological autonomy that is related to making own independent decisions, which could influence on their health (Currie et al., 2010).

In an academic level they have to face the challenges that require adapting to new environment, with new rules and higher academic workload, which show new stressors and high academic achievement (Leary \& DeRosier, 2012). In other words, these late adolescents have to develop an academic adaptation towards university.

To understand academic adaptation, Portuguese researchers used a psychosocial perspective and made questionnaires that measured three big domains: Student which is related to autonomy, competence and well-being. Course, which is related to academic achievement and how the person is succeeding in their academic career. Context which describes the institutional adaptation of the student with the academic environment (Almeida, Ferreira Soares, 2001; Soares, Almeida y Ferreira, 2006). Finally, these three big domains were divided into five subdomains: Personal (Personal or well being), Interpersonal (Interpersonal relationships), Career, Study and Institutional.
The first one is appointed to the student domain, the third and fourth to the course domain and finally, interpersonal and institutional to the contextual domain (Almeida et al., 2001; Almeida, Soares, \& Ferreira, 2002). If the person succeeds in these five domains then he/she has an adequate university adaptation.

The university environment shows a variety of demands that can cause stress in young people. For example, lack of time to finish all academic tasks, oral presentations, heavy academic workload and course evaluations (García-Ros, Pérez-González, Pérez-Blasco \& Natividad, 2012; Pozos-Radillo, Preciado-Serrano, Acosta-Fernández, AguileraVelasco \& Delgado-García, 2014). In a qualitative study, Sevinc and Gizir (2014) found out that perception of distant teachers was related to the university adaptation process. Furthermore, peer relations, leisure time and participation in recreational activities were positively related with a better social adaptation. Moreover, being shy, fear of being rejected by others and identity were related to personal adaptation. Finally, sense of belonging to a group was also positively related to institutional adaptation.

Furthermore, Pozos-Radillo et al., (2014) found in 527 Mexican university students that class participation, mandatory tasks and exams predict chronic symptoms of stress. This could be very important because high levels of stress are related to low academic adaptation. In that case, adaptation is also related to health in late adolescents and emerging adults.

Self-perceived health is the subjective perception of how healthy physically and mentally a person feels. The person could feel healthy but when he or she is evaluated by a doctor founds out that is not (Schwartzmann, 2003). Besides, a person could not feel any physical discomfort but regardless of that does not feel healthy (Ardila, 2003).

Hussain, Guppy, Robertson and Temple (2013) found that stress has a negative relationship with a lower perception of health in late adolescents. Therefore, they also found that late adolescents that suffered higher levels of stress had more health problems, more fatigue, which was related with a less class attendance, more feelings of dropping out from college and less enjoyment of university. Other studies have found out that late adolescents that perceive a better health also feel they have a better academic achievement in comparison to the ones that have a lower self-perceived health (Ansari \& Stock, 2010). Furthermore, late adolescents that have less physical health, less well-being and little social support and lower satisfaction towards their courses tend to consider school dropout (Hixenbaugh, Dewart \& Towell, 2012).

As a result of all these, it is very important to study the relationship of university adaptation and health in late adolescents and emerging adults. It appears that they have a strong bond with each other, but we don't know much of what specific domains are more related to health in late adolescents and emerging adults. Empirical research gives evidence that the developmental level and academic level are important for late adolescents and emerging adult's health.

Therefore, the aim of this study was to assess the relationship between university adaptation, perceived stress and mental and physical health. Moreover, we evaluated if perceived stress 
mediated the relationship between university adaptation variables and mental and physical health.

\section{Method}

\section{Participants}

A cross-sectional study was carried out among general studies undergraduate students of one private university in Lima, the capital of Peru. The sampling frame consisted of undergraduate students studying in Peru which studied Basic general studies ( $n$ $=200$ ). Students were not selected randomly. Ethical permission for the study was issued by the Commission on research ethics for basic general studies.

Of the 200 students, 67 were male (33.5\%) and 133 female $(66.5 \%)$. Mean age was 18.13 years old $(\mathrm{SD}=1.41)$ and ranged between $16-27$ years old. The majority of cases were born in Lima (77.8\%) and $22.2 \%$ were born in other places. $72.5 \%$ of the people have never failed a course and $27.5 \%$ had failed one course.

\section{Instruments}

\section{Mental and physical health}

Self-perceived health was measured using the SF-36 scale, which has 36 items and 8 scales organized into 2 big components, Physical Health and Mental Health. Higher scores indicate better physical and mental health (Ware, Snow, Kosinski \& Gandek, 1993). Salazar and Bernabé (2012) validated the SF-36 scale for Peru and reached an internal consistency of .88. The eights scales (Emotional role, Social Functioning, Vitality, Mental Health (well-being), Physical functioning, Physical role, Bodily pain and General health) ranged a Cronbach alpha between .66 and .92. A CFA model showed an adequate goodness of fit in CFI, TLI, RMSEA and SRMR for an 8 eight subscale separated in two high order latent variables (mental and physical health). Mental health was comprised in emotional role, social functioning, vitality and mental health. Meanwhile, Physical health consisted on Physical functioning, Physical role, Bodily pain and General Health.

\section{Perceived stress}

Perceived stress was measured by using the Spanish version of the Perceived stress scale (PSS). This scale has 14 questions and uses a Likert scale from 1 to 5. Items, 4, 5, 6, 7, 9, 10 and 13 has reversed scoring. Higher scores mean bigger amounts of perceived stress in the last month. The PSS showed and adequate internal consistency of .82 and a high test-retest correlation .73 . Furthermore, the PSS also showed concurrent validaty with a distress $(r=.71)$ and anxiety test $(r=.64)$ (HADS-T and HADSA) (Remor, 2006; Gonzalez \& Landero, 2007).

\section{University adaptation}

The "Cuestionario de Vivencias académicas" (QVA-r) or in English Questionnaire of Academic Experience (QAE) was used to measure university adaptation. This questionnaire has 60 items for 5 subscales and uses a Likert scale from 1 to 5 . (Almeida, Soares, Ferreira \& Tavares, 2004). The five subscales are: "Personal" which measures well-being, "Interpersonal" that is related to interpersonal relationships; "Study", which evaluates academic achievement, "Career" that measures future career perspective and "Institutional" which evaluates the familirty the student has with the facilities in his institution. Scoring for higher scores mean better adaptation (Márques, Ortiz \& Rendón, 2009), these subscales showed an adequate Cronbach alpha, which ranged between .71 ("Institutional) and .97 "Career". Furthermore, the total explained variance between each subscale ranged between 5.4\% ("Institutional") and $10.6 \%$ ("Personal") For this study, we used the Peruvian version of the QVAr (Chau \& Saravia, 2014a).

\section{Statistical Methods}

Questionnaires were coded for each participant. Data was collected by using paper-based questionnaires.

For all variables total scores were calculated and used for analysis. Two models were made for each variable. Variables highly correlated were not included in order to avoid multicollinearity. Kurtosis and Skewness lower than 1 criterion were used to test for normality and justify the use of multiple linear regressions (Tabachnick \& Fidell, 2013). Finally, significance level was set at 0.05 .

\section{Procedure}

The instruments were administered in 30 minutes sessions and participation was voluntary. Data analysis techniques are described in the Results Section.

\section{Results}

We situate for each scale the mean score on the possible range of scores, we see the following pattern:

- Mental health scores are just above the midpoint (50). Furthermore, all subscales of mental health (general) were hire the mid-point of the scale (50). Vitality and emotional role were the lowest scales and were nearest to the mid-point. Social functioning was the highest subscale and is well higher from the mid-point.

- Meanwhile, in Physical health the mean scores are much higher than the midpoint (50). General health is the lowest subscale of physical health. In spite of this, it is above the midpoint of the scale (50). Physical role and bodily pain were also above the mid-point of the scale which means a better physical health. Finally, physical function was the highest subscale and was well over the mid-point and had almost the highest possible score of the whole scale.

Perceived stress: the mean score is below the midpoint of 22 . We do now the same for the University adaptation variables. 
Table 1

Mean score, standard deviation, alpha's and possible range for each of the health measures.

\begin{tabular}{|c|c|c|c|c|c|}
\hline Variables & Cronbach $\alpha$ & Coding( $\left.{ }^{*}\right)$ & M & $\mathrm{SD}$ & Possible range \\
\hline Mental Health (General) & .88 & + & 63.32 & 19.62 & $0-100$ \\
\hline Emotional role & .77 & + & 56.95 & 40.69 & $0-100$ \\
\hline Social Functioning & .81 & + & 73.75 & 21.78 & $0-100$ \\
\hline Vitality & .79 & + & 55.96 & 40.69 & $0-100$ \\
\hline Mental health (well-being) & .86 & + & 66.50 & 17.56 & $0-100$ \\
\hline Physical Health & .85 & + & 75.79 & 15.70 & $0-100$ \\
\hline Physical functioning & .80 & + & 91.01 & 12.26 & $0-100$ \\
\hline Physical role & .76 & + & 74.63 & 32.53 & $0-100$ \\
\hline Bodily pain & .80 & + & 74.74 & 21.05 & $0-100$ \\
\hline General health & .78 & + & 62.28 & 17.14 & $0-100$ \\
\hline Perceived stress & .92 & - & 20.21 & 7.94 & $0-44$ \\
\hline \multicolumn{6}{|l|}{ University Adaptation } \\
\hline Personal ${ }^{*}$ & .93 & + & 27.92 & 10.23 & $0-48$ \\
\hline Interpersonal $^{*}$ & .91 & + & 31.51 & 9.81 & $0-52$ \\
\hline Institutional $^{*}$ & .74 & + & 23.93 & 4.64 & $0-32$ \\
\hline Study ${ }^{*}$ & .88 & + & 35.49 & 8.52 & $0-56$ \\
\hline Career ${ }^{*}$ & .89 & + & 27.71 & 7.74 & $0-40$ \\
\hline
\end{tabular}

$+=$ the higher, the healthier; $-=$ the lower, the healthier

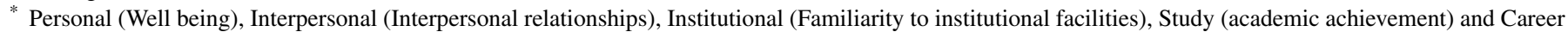
(future career perspective).

Table 2

Models for the estimation of mental and physical health.

\begin{tabular}{|c|c|c|c|c|c|c|}
\hline & & $B$ (coeff) & $95 \% \mathrm{CI}$ & $\beta$ & $t$ & $P$ value \\
\hline \multirow[t]{3}{*}{ Mental health } & Interpersonal & 0.50 & $0.21-0.78$ & .25 & 3.46 & $<0.001$ \\
\hline & Study & 0.46 & $0.12-0.79$ & .20 & 2.64 & $<0.01$ \\
\hline & Career & 0.44 & $0.09-0.79$ & .18 & 2.50 & $<0.01$ \\
\hline \multirow[t]{2}{*}{ Physical health } & Perceived stress & -0.76 & $-1.06--0.47$ & -.39 & -5.10 & $<0.001$ \\
\hline & Study & 0.26 & $-0.02-0.53$ & .14 & 1.85 & $=0.07$ \\
\hline
\end{tabular}

Note: Mental health: $\mathrm{R}^{2}=.23(\mathrm{~N}=186, \mathrm{p}<.001) . \mathrm{CI}=$ Confidence interval for $\mathrm{B}$.

Physical health: $\mathrm{R}^{2}=.22(\mathrm{~N}=189, \mathrm{p}<.001) . \mathrm{CI}=$ Confidence interval for $\mathrm{B}$.

Personal: the mean score is above the midpoint 24 of the scale. Interpersonal: the means score is above the midpoint 26 of the scale. Institutional: the mean score is very much above the midpoint 16 of the scale. Study: the mean score is much above the midpoint 28 of the scale. Career: the mean score is above the midpoint 20 of this scale. Table 1 Table 2

\section{Models for predicting mental and physical health on students}

Regression models to estimate mental and physical health were performed including all the variables that correlated with that variable.

Multiple linear regression estimations had the following results for mental health. According to our findings, interpersonal relationships in university better related to mental health. Furthermore, this model was composed by three variables (Interpersonal, Study and Career), which accounted for $23 \%$ of the whole model. Career was the variable that least explained mental health.

On the other hand, perceived stress better explained the relationship with physical health. This model was composed of perceived health and Study which accounted for $22 \%$ of the whole model of physical health.

Mediation analysis was performed for the physical health model. The Sobel test proved to be significant $(z=4.34, p<$ 0.001 ) with an indirect effect of 0.38 . Study was not significant when perceived stress was added to the model, therefore this variable fully mediated the relationship between study and physical health. A mediation analysis for mental health wasnt conducted due to the similarities between mental health and perceived stress causing the model to be biased. Figure 1

\section{Discussion}

The aim of this study was to assess the relationship between university adaptation, perceived stress and mental and physical health. Moreover, we evaluated if perceived stress mediated the relationship between university adaptation variables and mental and physical health.

Interpersonal, had the strongest relationship with a better mental health. This could be due to the following: Social support under stressful situations is associated with positive effects and reduces mental and physical health disorders. Furthermore, affiliation with other or "befriending" is vital for health and 


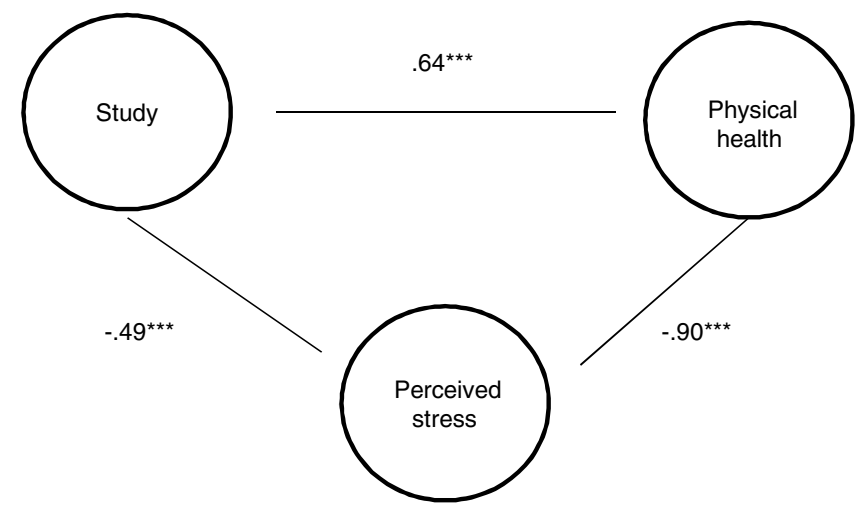

Figure 1. Mediation model for physical health.

for managing threating circumstances (Taylor \& Master, 2011). Social networks functions in health in different ways: First, they serve as social support as a provision of care and aid in times of need which reduces psychological distress. Second, these networks provide enjoyable interactions. These relationships provide enjoyable activities, positive affect and stimulation. Meanwhile, less companionship could derive into negative affect and reduce the possibility to develop psychological resources to withstand life stressors (Rook, August \& Sorkin, 2011). Third, social relations could also function as social control, were the network members monitor, encourage and persuade another person to adhere to positive health practices (Thoits, 2011). This could also be relevant because it is possible that peer could encourage one another to study more, compare notes and have study groups in order to be better prepared for academic demands. This could be very important because if these coping skills such soliciting social support are used during adolescence it is highly probable that the person will keep using it threw adulthood (Seiffge-Krenke \& Beyers, 2005).

Study was also related to mental health. In this case, findings have shown that students of this college's academic unit feel that they can cope with the academic demands. In spite of this, these students feel that academic evaluations could be a very difficult task to cope with and $38 \%$ of students have had some difficulties organizing themselves and dealing with daily academic demands (DAA, 2012). As we found out, the ability to cope with all these concerns could be related to a better perception of mental health. Additionally, Boullosa (2013) also states that the most common reaction of student when they were feeling overwhelmed by academic demands was exhaustion and somnolence that is related to a lack of vitality. These findings are linked with the results from this study, were a less amount of vitality also affects overall mental health.

Career was also positively related to a better mental health. Studies have shown that future oriented problems are more stressful than even family problems and cause fear and worries of future unemployment or future occupation (Seiffge-Krenke, 1998). Likewise, other findings have shown that the principal reason for this student's to go to college is to develop skills that could help them in their future jobs (Dirección de Estudios Académicos, 2012). Altogether, school and career issues are highly important in adolescence, academic achievement and job selection represents a big part of their concerns (SeiffggeKrenke, 2001). This could be a possible explanation why we found out that variables regarding study workload and future academic goals could be related to mental health. Furthermore, findings have suggested that minor stressors such as academic workload that are common in a college environment explain more variance of psychological symptoms than critical life events (Seifgge-Krenke, 1998). This could be another explanation why Interpersonal, Study and Career which describes social support, adaptation towards academic workload and future perspective of academic goals and career (Almeida, Ferreira \& Soares, 1999), is related to a better psychological health. Other important topics related to health in adolescents are growing academic expectations, changing social relationships with family and peers, the physical and emotional change with maturation and the considerable amount of change they have to face. These changes, are regarding autonomy and independent decision making that could influence on their health (Currie et al., 2010).

Perceived stress could have had a mediating effect on the relationship of study and physical health due to the effects of stress in the body. As a result of heavy academic workload, university students could be suffering from chronic stress and feel physical symptoms such as headaches or fatigue (Barraza, 2006). Furthermore, another study found that student's most frequent and challenging concerns were regarding, stress and time management (Reynolds, 2013), which are related to their ability to cope with stressful situations and university adjustment. This condition could cause a malfunction in the negative loop which is designed to shut down the response to threating situations and maintain homeostasis (Henderson \& Baum, 2004) which consequently can promote biological damage and symptoms of bodily pain and inevitably become stressors (Gatchel, Howard \& Haggard, 2011). Moreover, other study findings were also related to these results, were perceived stress measured threw perceived pressure and demands were related to psychosomatic symptoms, headaches and upper respiratory infections and musculo-skeletical pain (Wiklund, Malmgren-Olson, Ohman, Bergstrom \& Fjellman-Wiklund, 2012).

This has important implications for these study findings; in this case, physical health was measured by grouping physical functioning, physical role, bodily pain and general perception of health measured physical health. Furthermore, in this study general health was the scale that had the least score, in this case there is the possibility that student's perceived health is the variable that is affected the most from a heavy academic workload. These findings are very important not only for late adolescent's health at this moment, but also for the future. Hoyt, Chase-Landsdale, Mcdade \& Adam, (2013), found that adolescent's positive wellbeing was associated to better perceived health and fewer risky behaviors during young adulthood.

Some limitations were assessed for this study. This sample was collected from just one college in a single providence of Peru. Future studies could also include other universities from different cities of Peru and also several different universities in Lima. Furthermore, this sample included students that were immigrants, this could have affected our findings because of the 
challenges this people could face due to acculturation, which involves a process of adaptation to new norms and rules (SeiffgeKrenke, 1998). Future studies could focus on the comparison between immigrants' students and non-immigrants in order to assess if there are any difference in their college adaptation. Furthermore, personality traits were not controlled for this study. It is possible that better students could have more consciousness, which could help them develop more skills to cope with academic demands, and for that matter have a better health (Mathews, Zeidner \& Roberts, 2006).

This study assessed mental and physical health of college students in Peru and which factors are stronger related to an overall health. Our findings could help further understand how college students are adjusting in order to have a better health. This could be very helpful because it gives information that could be used on interventions of students that are struggling to adequately adapt to college demands. Healthy students could have a better college experience, learn more and be more prepared for future challenges such as job demands and competition. Furthermore, a more skilled work force could enhance economic growth and development in Peru.

\section{References}

Almeida, L., Ferreira, J., \& Soares, A. P. (1999). Questioario de vivencias academicas (QVA E QVA-R). Portugal: Universidade do Minho.

Almeida, L., Ferreira, J., \& Soares, A. P. (2001). Questionário de Vivências Académicas: Construção e validação de uma versão reduzida (QVA-R). Manuscrito no publicado.

Almeida, L., Soares, A. P., \& Ferreira, J. (2002). Questionário de Vivências Académicas Avaliação do ajustamento dos estudantes universitarios. Avaliação Psicológica, 2, 81-93.

Almeida, L., Soares, A. P., \& Tavares, J. (2004). Transicao e Adaptacao a Universidade: Apresentacao de Alguns Instrumentos de Medida. En Machado, C., Almeida, L., Goncalves, M \& Ramalho, V. (2004). Avalicao Psicológica. Formas e Contextos. Braga: Portugal.

Ansari, W., \& Stock, C. (2010). Is the health and wellbeing of University Students Associated with their Academic Performance? Cross Sectional Findings from the United Kingdom. International Journal of Environmental Research Public Health, 7(2), 509-527. http://dx.doi.org/10.3390/ijerph7020509

Ardila, R. (2003). Calidad de vida: una definición integradora. Revista latinoamericana de psicología, 35(2), 161-164.

Barraza, A. (2006). Un modelo conceptual para el studio del estres academico. Revista electronica de psicologia iztacala, 9, 110-129.

Boullosa, G. (2013). Estrés académico y afrontamiento en un grupo de estudiantes de una universidad privada de Lima. Tesis de licenciatura. Lima: Pontificia Universidad Católica del Perú.

Chau, C., \& Saravia, J.C. (2014a). Propiedades Psicométricas del instrumento de adaptación universitaria (QVA-R) en Perú. Universitas Psychologica.(En prensa).

Currie, C., Zanotti, C., Morgan, A., Currie, D., de Looze, M., Roberts, C., Samdal, O., Smith, O., \& Barnekow, V. (2010). Social determinants of health and well-being among young people. Health behavior in school aged children (HSBC) study. International report from the 2009/2010. Survey. Copenhagen: WHO regional office for Europe.

Dirección de Estudios Académicos, oficina para las mejoras académicas (DAA). (2012) Las características de los ingresantes a la PUCP y su relación con el rendimiento.

García-Ros, R., Pérez-González, F., Pérez-Blasco, J., \& Natividad, L. (2012). Evaluación del estrés académico en estudiantes de nueva incorporación a la universidad. Revista Latinoamericana de Psicología, 44(2), 143-154.

Gatchel, R., Howard, K., \& Haggard, R. (2011). Pain: The Biopsychosocial perspective. In R. Contrada, \& A. Baum (Eds.), The Handbook of stress science: Biology, psychology and health. New York: Springer publishing company.

González, M., \& Landero, R. (2007). Factor structure of the perceived stress scale (PSS) in a sample from Mexico. The Spanish Journal of Psychology, 10(1), 199-206. http://dx.doi.org/10.1017/S1138741600006466

Henderson, B. N., \& Baum, A. (2004). Biological mechanism of health and disease. In S. Sutton, A. Baum, \& M. Johnson (Eds.), The sage handbook of health psychology. London: Sage.

Hixenbaugh, P., Dewart, H., \& Towell, T. (2012). What enables students to succeed? An investigation ofsocio-demographic, health and student experience variables. Psychodynamic Practice, 18(3), 285-301. http://dx.doi.org/10.1080/14753634.2012.695887

Hoyt, L., Chase-Landsdale, P., Mcdade, T., \& Adam, E. (2013). Positive youth, healthy adults: Does positive well-being in adolescence predict better perceived health and fewer risky health behaviors in young adulthood? Journal of adolescence health, 50, 66-73. http://dx.doi.org/10.1016/j.jadohealth.2011.05.002

Hussain, R., Guppy, M., Robertson, S., \& Temple, E. (2013). Physical and mental health perspectives of first year undergraduate rural university students. Bio Med Central Public Health, 13, 1-11. http://dx.doi.org/10.1186/1471-2458-13-848

INEI. (2013). Estado de la población peruana 2013. Recuperado de http://www.inei.gob.pe/media/MenuRecursivo/publicaciones_digitales/Est/ Lib1095/libro.pdf.

Leary, K., \& DeRosier, M. (2012). Factor promoting positive adaptation and resilence during the transition to college. Psychology, 3(12), 1215-1222. http://dx.doi.org/10.4236/psych.2012.312A180

Márquez, D., Ortiz, S., \& Rendón, M. (2009). Cuestionario de Vivencias Académicas en su versión reducida (QVA-r): un análisis psicométrico. Revista Colombiana de Psicología, 18(1), 33-53.

Mathews, G., Zeidner, M., \& Roberts, R. D. (2006). Models of personality and affect for education: A review and synthesis. In P. Alexander, \& P. Winne (Eds.), Handbook of educational psychology. Taylor \& Francis.

Ministerior de salud del Perú (MINSA). (2011). Análisis de la situación de salud 2011. Dirección de salud V Lima ciudad. Diciembre 2011. Lima: Autor.

Pozos-Radillo, B., Preciado- Serrano, M., Acosta- Fernández, M., AguileraVelasco, M., \& Delgado García, D. (2014). Academic stress as a predictor of chronics stress in university students. Psicología Educativa, 20, 47-52. http://dx.doi.org/10.1016/j.pse.2014.05.006

Remor, E. (2006). Psychometric properties of a european spanish version of the perceived stress scale (PSS). The Spanish Journal of Psychology, 9(1), 86-93. http://dx.doi.org/10.1017/S1138741600006004

Reynolds, A. (2013). College students concerns: Perceptions of students affairs practitioners. Journal of College Student Development, 54, 98-104. http://dx.doi.org/10.1353/csd.2013.0001

Rook, K., August, K., \& Sorkin, D. (2011). Social Network functions and health. In R. Contrada, \& A. Baum (Eds.), The Handbook of stress science: Biology, psychology and health. New York: Springer publishing company.

Salazar, B., \& Bernabé, E. (2012). The spanish SF-36 in Peru: Factor structure, construct validity and internal consistency. Asia Pacific Journal of Public Health, 13, 1-9. http://dx.doi.org/10.1177/1010539511432879

Schwartzmann, L. (2003). Calidad de vida relacionada con la salud: aspectos conceptuales. Ciencia y enfermería, 9(2) http://dx.doi. org/10.4067/S0717-95532003000200002

Seiffge-Krenke, I. (1998). Adolescents's health. A developmental perspective. London: Lawrence ErlBaum associates, publishers.

Seiffge-Krenke, I., \& Beyers, W. (2005). Coping trajectories form adolescence to young adulthood: Links to attachment state of mind. Journal of research on adolescence, 15, 561-582. http://dx.doi.org/ 10.1111/j.1532-7795.2005.00111.x

Seiffge-Krenke, I. (2001). Diabetic adolescents and their families. Stress, coping and adaptation. Cambridge University Press. http://dx.doi.org/ 10.1017/cbo9780511500022

SENAJU. (2012). 1 ra Encuesta Nacional de la Juventud. Fondo para el Logro de los ODM. Recuperado de http://juventud.gob.pe/libro-electronico-enajuv/.

Sevinc, S., \& Gizir, C. A. (2014). Factors Negatively Affecting University Adjustment from the Views of First-Year University Students: The Case 
of Mersin University. Educational science theory and practice, 14(4), 1301-1308.

Soares, A. P., Almeida, L. S., \& Ferreira, J. A. (2006). Questionário de Vivências Académicas: Versão integral (QVA) e versão reduzida (QVAr). En M. M. Gonçalves, M. R. Simões, L. S. Almeida, \& C. Machado (Coords.), Avaliação psicológica: Instrumentos validados para a população portuguesa (Vol. 1, pp. 101-120). Coimbra: Portugal.

Taylor, S., \& Master, S. (2011). Social responses to stress: The tend-and-befriend model. In R. Contrada, \& A. Baum. (Eds.), The Handbook of stress science: Biology, psychology and health. New York: Springer publishing company.
Tabachnick, B., \& Fidell, L. (2013). Using Multivariate Statistics (6th edition). London: Pearson

Thoits, P. (2011). Mechanisms linking social ties and support to physical and mental health. Journal of health and social behavior, 52, 145-161. http://dx.doi.org/10.1177/0022146510395592

Wiklund, M., Malmgren-Olson, E., Ohman, A., Bergstrom, E., \& FjellmanWiklund, A. (2012). Subjective health complaints in older adolescents are related to perceived stress, anxiety and gender - a cross-sectional school study in Northern Sweden. BMC public health, 12, 1-13. http://dx.doi.org/10.1186/1471-2458-12-993 